\title{
Dark ecology and the representation of canids in Deon Meyer's Fever
}

\author{
Bibi Burger
}

Bibi Burger is a lecturer in the Department of Afrikaans at the University of Pretoria. Email: bibi.burger@up.ac.za

\section{Dark ecology and the representation of canids in Deon Meyer's Fever}

Deon Meyer's post-apocalyptic novel, Fever, opens with Nico Storm, the narrator, and his father being attacked by dogs. Nico is only thirteen years old, but is forced to shoot the dogs to rescue his father. This incident sets the scene for the rest of the novel. It characterises Nico and his father and their relationship. It also informs the reader about the world in which the novel is set. Fever opens a few months after ninety-five percent of the world's population died as the result of a mysterious virus-one engineered in an attempt to redress ecological imbalances. In this article, the representation of dogs and other canids in Fever is used as a departure point to bring the worldviews of the various characters into dialogue with Timothy Morton's Dark Ecology. It is argued that the different worldviews (and the place accorded to canids in each) have political and ecological implications. Most of the worldviews can be understood in terms of what Morton calls the "agrilogistic loop" because they are based on the assumption that humans can and should manipulate the nonhuman. Two characters' view of canids are, however, closer to what Morton terms "ecognosis", because they acknowledge humans' (and canids') entanglement with the rest of nature. Keywords: Dark Ecology; Deon Meyer; dogs in literature; ecocriticism; Fever; object-oriented ontology; speculative fiction; Timothy Morton.

\section{Introduction}

Deon Meyer's novel, Fever (2017), differs from the rest of his oeuvre. Fever does contain elements of the detective fiction Meyer is famous for. It is, however, primarily a post-apocalyptic novel that can be classified as speculative fiction. It therefore represents an attempt to imagine the future, a specific version of the near future-one in which ninety-five percent of the world's population has died as the result of a virus (Meyer 52). Different sections of the book are narrated by different characters, but the main narrator and protagonist is Nico Storm. At the start of the novel, he and his father, Willem, are travelling across South Africa, 
Dark ecology and the representation of canids in Deon Meyer's Fever

trying to establish a new community. They eventually succeed in establishing the "republic" of Amanzi in the ruins of the small town of Vanderkloof. Two noteworthy characters who play leadership roles in Amanzi are Ryan Domingo, who establishes a military defence unit, and Pastor Nkosi Sebego, a preacher and Willem's political rival. One of the aims of this article is to argue that various views of society are played off against each other in Fever. These societal views include Willem's democratic humanism and Domingo's Darwinistic views. It also includes the ecological view of Gaia One and Nico's mother.

In this article, Timothy Morton's theorisation around what he calls "dark ecology" will be used to argue that the political systems that are represented in the novel all have different ecological implications. The systems not only involve different views of society, but also different views of the relationships between humans and the rest of the world. I am especially interested in the ways in which the characters' views of canids are representative of the way they conceive humans' relationship with nonhuman nature. In this respect, dogs play a symbolic role in Fever similar to that which Morton reserves for cats: "Cats weirdly symbolize the ambiguous border between agricultural logistics and its (impossible to demarcate) outside" (Morton Dark Ecology loc. 41). He says that we see dogs as completely domesticated, and therefore completely part of agricultural logistics, but that, as cats are less tamed, "[i]t's as if we use cats to prove to ourselves that there is a Nature". In the post-apocalyptic world of Fever, however, dogs (like humans) are situated on the border between agrilogistics and its "outside". Dogs and humans are still influenced by their positions in the pre-fever world, but they are now immersed in different forms of co-existence with the rest of "nature".

The different characters' ideologies entail different ways of viewing the relationships between humans and the rest of nature. Canids feature specifically in three characters' ideologies-Willem, Domingo and Meklein. It will be argued that their references to dogs and other canids can be used to understand the ecological implications of their ideologies because canids represent, for them, the "ambiguous border" between the human and the nonhuman.

\section{Agrilogistics and anxiety}

In Amanzi, each year after the fever is named for encounters with animals. The novel opens with "The year of the dog", named to commemorate an incident described in the first pages of Fever. At this time, eleven months after the fever, Nico is thirteen years old. He and his father are travelling in a truck across rural South Africa, looking for resources. They stop for fuel at an abandoned garage. Here they are attacked by a pack of dogs that presumably grew feral after their owners died. 
Willem orders his son to get a pistol from the truck and shoot the dogs. Nico manages to shoot some of the dogs and in so doing scares off the rest. These events set the scene for the rest of the novel. For the first time Nico realises that his father is human and vulnerable and cannot always protect him (Meyer 26; 34-5). This is foreshadowing for the psycho-analytic flavoured noir structure of the novel to come: Nico will eventually be confronted with the fallibility of all of his parental figures. Nico's shooting of the dogs to protect Willem also establishes the roles that both characters will eventually play in Amanzi. Willem is the pacifist and humanist who cannot kill a dog, but who needs the violence of Nico and Domingo to protect his life and ideals.

In the near future world represented in the novel, domesticated dogs have returned to their wild state. This can be read symbolically, as foreshadowing for the "wild" humans Nico and Willem will meet throughout the novel. It can also be read literally, as an indication of how the world has changed after the fever. Humans and dogs are no longer companion species-dogs hunt humans and they compete with humans for food. This is also an indication of how humans have changed after the fever. Humans are no longer the dominant species, able to shield themselves from the rest of the world. Although they still have some technological advantages (for instance the pistol Nico uses to shoot the dogs), they are on a (more) equal footing with dogs.

In this world foxes run through the streets of towns (14), snakes glide through supermarkets (42), elephants wander the countryside (61) and pigeons live in hotel lobbies (63). Nonhumans therefore reclaim some of the spaces formerly inhabited by humans. In the immediate post-fever world, humans are not the owners, custodians or keepers of animals. This changes again as human societies are re-established.

The interpretation of Amanzi as an attempt to re-establish the pre-fever world will be defended later in the article. For now, it should be mentioned that this reestablishment is also partly a response to the threat of dogs. Willem tells Nico that they will have to start cattle farming, since the dogs are wiping out the roaming animals $(70,107,109)$. Although Willem fantasises that post-fever Africa equals pre-colonial Africa, this world is not a clean slate but is still influenced by the pre-fever world and human actions within it. If it were not for the domestication of dogs, the feral dogs would not have been a problem. As Sofia Bergman (Nico's love interest) remembers her father (a farmer) saying about another canid, jackals:

He always said it was our fault the jackals became so clever. Because the people, the farmers, shot out all the dumb jackal, and only the clever ones survived, and they bred with each other, and so the farmers unintentionally applied their own genetic manipulation and bred a super-jackal. That's why it became impossible to eradicate jackal in the Karoo (241-2). 
Dark ecology and the representation of canids in Deon Meyer's Fever

This attempt to protect humans and agricultural human projects therefore lead to (unpredictable) ecological problems. At the end of Fever Nico finds out that the fever was not a natural occurrence, but an engineered attempt to fix ecological imbalances (515). Similarly to the jackals in the Karoo, the packs of feral dogs in Fever are an example of the unpredictable results of human attempts at engineering nonhuman nature. The scientists of Gaia One (the society responsible for the fever) think reducing humans will save the earth from the problems resulting from over-population, including climate change (515). They, however, misjudge the far-reaching and irreversible effects of human domination.

In Dark Ecology (2016) Morton argues that humanity is currently in a state of anxiety: we have recognised some of the disastrous consequences of our attempts to control the rest of the world, but as yet we cannot seem to imagine a different way of existing. According to Morton every reaction to problems such as climate change seems to be based on the same principles that caused climate change in the first place. Dark Ecology follows on Morton's Ecology without Nature (2009), in which he contends that conventional ideas of "conserving nature" are counterproductive. These conventional approaches to environmental protection presupposes a divide between humans and nature, with humans being custodians of the latter. Humans created "Nature", "demarcating human systems from earth systems" and to think of humans as the conservationists of nature is to perpetuate this demarcation (Morton Dark Ecology loc. 1015). Morton rather proposes a form of ecological awareness that recognises that humans are a part of nature, just another animal (loc. 122). This ecological awareness is "dark": "dark-depressing", "dark-uncanny", but also "strangely sweet". Because dark ecology is not anthropocentric and posits that the over valuing of humans and human experiences is responsible for ecological destruction, dark ecology is not something that can be controlled by the human. Instead of "a knowing", Morton describes it as a "letting be known". He calls this "ecognosis":

[Ecognosis] is like becoming accustomed to something strange, yet it is also becoming accustomed to strangeness that doesn't become less strange through acclimation. [...] [T] he politics of coexistence are always contingent, brittle, and flawed, so that in the thinking of interdependence at least one being must be missing. Ecognostic jigsaws are never complete. (loc. 122-56).

Morton conceives of ecological awareness as consisting of realms through which humans must move: "Each descending layer [...] is a more accurate attunement of the basic anxiety inherent in sentient attunement to things" (loc. 2203). Morton proposes ecognosis as an alternative to the aforementioned "agrilogistics". In the next section Morton's theorisation on agrilogistics will be discussed and brought into dialogue with a broader ecological discourse.

By "agrilogistic loop" Morton means the way of thinking that involves the human assuaging his fears of death and non-existence by cultivating the earth

Tydskrif vir Letterkunde 55.3 (2018) 
and by demarcating everything, including his own thoughts, into neat units (loc. 758). ${ }^{1}$ Because of agrilogistics' loop shape, actions have unexpected consequences, and attempts to order the world and treat it as logical and controllable units are futile. Agrilogistics also involves humans valuing existence more than any quality of existence (loc. 816). People will, for instance, continue to procreate even though overpopulation lowers the quality of life and will continue extending farms even though it leads to ecological imbalances. Agrilogistic actions are doomed to failure because they are based on the assumption that the nonhuman can be manipulated by humans.

The discursive positioning of humankind as the crown of creation who can bend the rest of the world to their will was especially influential during modernity. As various theorists (for example Mies 223) argue, the rights of the modernist subject is built on the denial of rights to the abject Other. Non-European, nonwhite people, women, disabled people and nonhuman organisms and objects are viewed as subject to the white male's whims. The abjection of these people (leaving nonhumans aside for the moment) are justified by a teleological view of history. Mies refers to Hegel's theory that humanity is moving from barbarism to civility. The indigenous peoples of various colonies are viewed as still barbaric-it is the task of the European coloniser to civilise them (223).

This process does not only take place between different groups of people. The human subject also justifies his reign by classifying "nature" as abject. Even the human body is seen as something that needs to be overcome so that the human subject can become fully human (223). In this way man must transcend his natural state so that he is not only caught up in (and determined by) life cycles. According to Hegel this process can only take place when the Self distinguishes himself from the Other. When he does this, the Self becomes a subject while the (nonhuman as well as human) Other become objects.

Against this "opdonderingstaal,"- "fucking up language", as South African philosopher Marthinus Versfeld calls it (22) - various contemporary thinkers argue that new theoretical approaches are necessary that do not privilege the modernist human subject. Using terms such as New Materialism, Actor-network-theory (ANT), object-oriented ontology (OOO) and ontological realism, multidisciplinary thinkers argue that the world should not be divided into human subjects and nonhuman (or not human enough) objects. The bases of their arguments are varied, and not necessarily commensurable. Still, I will venture the claim that they all see the world as consisting of objects, of which humans are a specific type of object (Bryant 18). The human object should not be seen as more meaningful than all the other objects, and all the other objects should not only be valued in terms of their relationship to humanity. This does not necessarily imply that all objects are the same. Objects should be seen as heterogeneous, irreducible and autonomous, but no one object should be seen as more important than all the 
Dark ecology and the representation of canids in Deon Meyer's Fever

rest. The objects should rather be seen as related to each other in non-hierarchical ways. Bryant prefers the word "entangled" to describe these relationships (18). Morton's concept of ecognosis involves a "letting be known" of the entanglement of all things - and the human's inability to understand this entanglement from outside.

Ecognosis must be understood spatially, rather than in terms of "taking place" in linear time. As a person moves through the realms towards a "more accurate attunement to things", they move through various realms, but they do not leave the realms that they already passed through behind. They will again pass realms they have already moved through. History cannot be left behind, but will continue to exert an influence-often in illogical, surprising ways. As argued earlier, the dogs in Fever are symbolic of the ways in which history cannot be transcended. Gaia One attempted to create a new world in which humans and nonhumans would be able to live in a more sustainable ecosystem. They did not keep in mind that humans' domestication of dogs would cause packs of feral dogs to roam the world, killing other animals and destroying ecosystems. The threat of these dogs is also amongst the factors that compel people to start rebuilding societies again sooner than Gaia One had anticipated: Willem tells Nico that they will have to start cattle farming, since the dogs are wiping out the roaming animals (Meyer 70; see also 107,109$)$.

Morton also emphasizes that one must move downwards through various realms. He uses the term "subscendence" to indicate that we should not try to transcend or escape the "dark" emotions caused by the realization of our ecological destruction (Morton Dark Ecology loc. 1975). Rather, we should subscend into this darkness and so doing move through realms, including realms of anxiety, guilt, shame, disgust, melancholy and horror until we eventually reach more productive realms. For the sake of brevity only those realms that can be related to the specific characters' worldviews will be discussed.

The realization that we, as humans, will never truly have a grip on the world is anxiety provoking. The implication that the human is always entangled with other objects and cannot escape this entanglement, is uncanny. Humankind is always entangled with the earth: "Realizing we are on Earth in the full Earth magnitude way, realizing that we are permanently, phenomenologically glued to Earth even if we go to Mars, realizing that we are covered and brimful of skin, pollution, stomach bacteria, DNA from other lifeforms, vestigial organs-realizing all this is an experience of the uncanny" (loc. 2005).

Morton's use of the word "uncanny" is not coincidental. He considers humanity's realization that we are always entangled with earth as a variation of Freud's description of the unheimlichen as a realization of the subject's 'repressed intimacy' with the mother's body (Dark Ecology loc. 653). As with the subject's relationship with the mother's body, humans once experienced the earth as heimisch

Tydskrif vir Letterkunde 55.3 (2018) 
("homelike, familiar"), but our entanglement with and dependence on the earth, is now repressed. Realizing that we are not completely autonomous is uncanny and provokes anxiety. Climate change and the identification of the Anthropocene can be seen as uncanny events that bring humans to the realisation that our agrilogistic actions have unintended consequences and that we are not completely autonomous and rational, but are in fact dependent on an earth that is fragile.

It is not surprising, considering the influence of the agrilogistic loop, that humans' first reaction to the anxiety this realisation provokes is to search for answers within (agrilogistic) science and technology. Morton calls this approach "happy nihilism": "A violent nihilism is hardwired into agrilogistics. [...] A meadow could be a parking lot. Hey, let's build one-that sounds like a good idea! Let's build another road on the outer limits of the city! More people, more cars! Eventually this impulse is expressed as happy nihilism, the cheerful manipulation of extensional lumps, manipulation for manipulation's sake" (loc. 1822). "Happy nihilism" is seemingly currently the dominant discourse. The unexpected consequences and unconscious biases of scientism and humanism have become apparent, but humans are still caught within agrilogistics in our attempts to solve the problems caused by agrilogistics.

Although in Fever Gaia One's approach (reducing the world's human population to restore ecological balance) contradicts the agrilogistic principle that existence is inherently more valuable than any qualities of existence, it still assumes that humans can and should control the rest of the earth. In this respect, it corresponds to the way Morton characterizes certain contemporary scientists' views: "We have always been terraforming, so let's do it consciously from now on" (loc. 407). Morton (loc. 408) is not convinced: "[m]aking something conscious doesn't mean it becomes nice" and "[b]eing aware of 'unconscious biases' is a contradiction in terms". The problem with "conscious terraforming" also relates to scalethe human individual cannot be aware of the impact their actions will have on a planetary scale. As already mentioned, in Fever these unexpected consequences are especially represented by the dogs in the post-fever world, wreaking havoc on ecosystems. Gaia One presumably did not keep in mind that domesticated dogs will not die with their owners and reducing the earth's human population is not enough to restore ecological balance. As mentioned earlier, it is partly the threat of dogs that causes human communities and settlements to form quicker than Gaia One had calculated. Nico, in agrilogistical fashion, attributes the failure of Gaia One's calculations to "mankind's ingenuity, the ability to solve problems and overcome circumstances" (Meyer 524). One of the problems they feel the need to "overcome" is the threat of dogs to their lives and their attempts at livestock farming $(70,107$ and 109). In turn the behaviour of the (formerly domesticated) dogs is influenced by the virus killing their former human companions and source of food. Nico and Jacob Mahlangu, as sheep-herders, have to shoot a pack of thirty 
Dark ecology and the representation of canids in Deon Meyer's Fever

dogs. Nico relates the dogs' unusual behaviour, hunting sheep in "broad daylight", to them "starving in this dreadful winter" (109).

Nico's belief in "mankind's ingenuity" is similar to that of his father, Willem. Although it might seem as if Willem's humanism is the exact opposite of Gaia One's scientific view, he is also attempting to find solutions to the problems of agrilogistics (ecological crises) within agrilogistics. He is angry with Gaia One for interrupting what he sees as humanity's progress. He believes that, if it were not for the fever, humans would have found other solutions to ecological disasters using "intelligence and renewed thought and astounding technology" (518). Willem believes in the myth of humanity's exceptional status (298) and teleological progress and tries to resume this project in Amanzi. He summarises these views:

Aren't you also amazed by what we're capable of? Look at our journey, Homo sapiens' journey, look how incredibly far we've come, from savannah prey to a robot on Mars and the splitting of the atom and the decoding of DNA. And democracy, reason and rationalism. Science above superstition, facts above myths [...] I wonder if the greater harm wasn't the interruption of what we were on the road to accomplishing. (519)

Some of the limitations of Willem's approach have already been implied, in that his pacifist philosophy needs the violent protection of Domingo and Nico. His faith in democracy also allows Pastor Nkosi to attempt a coup (222) and later to leave to establish a new community, New Jerusalem (370).

\section{The realms of guilt, melancholy and horror}

After the anxiety of first realising agrilogistics' disastrous consequences (and attempting to find solutions within agrilogistics), Morton claims that one moves into the realm of guilt. Morton contends that the realization of humankind's entanglement with the rest of the world takes the form of a film noir (Morton Dark Ecology loc. 200). In a classic film noir the detective is hired to solve a crime or mystery, but he (the detectives are usually male-see Krutnik xiii) eventually discovers that he and his personal history are implicated in the crime (Telotte 7). His discovery reveals something about himself that he has repressed (8). In the same way, the individual human who investigates large-scale ecological crises will eventually discover his or her own guilt: "I'm the detective and the criminal! I'm a person. I'm also part of an entity that is now a geophysical force on a planetary scale" (Morton Dark Ecology loc. 184).

Like in a film noir, it might initially seem as if Nico is investigating one crime, the murder of his father. This murder, however, only occurs late in the novel (on page 445 of 532 total pages). It also, in typical noir fashion, turns out to be the result of a much bigger crime. Following clues, Nico finds out that his mother is a

Tydskrif vir Letterkunde 55.3 (2018) 
member of Gaia One (Meyer 510). Her security team accidentally killed Willem when they were trying to abduct him to take him to his wife (526). The crime of Willem's murder was just one part of the bigger crime of the murder of the majority of the world's population. In this way, Nico finds out that he is (indirectly) implicated in this crime. Apart from being related to one of the perpetrators, he had received a vaccine without being aware of it (517).

Through his investigation, the noir detective discovers uncanny truths, often of an Oedipal nature (Hilfer 14). These discoveries provoke anxiety, but also a sense of guilt, as the detective discovers that he is not a detached observer, but personally involved with the crime. In Fever Nico's main discovery is his mother's guilt, but all of the plot lines in the novel have a noir-like structure. The novel opens with his realization that his father is not as strong as he thought and that, in future, he will have to protect him (first against dogs and later against other humans), instead of the other way around. This realization of his father's weakness is compounded by other instances, for example, when Pastor Nkosi outmanoeuvres Willem (Meyer 372).

Nico is also disillusioned by his other father figure, Domingo. Domingo is the military leader of Amanzi. Nico joins Domingo's team and idealizes him, partly because he is the opposite of his (disappointing, to Nico) father (73). Domingo claims that before the fever he had a "paramilitary occupation" (87). Nico and the reader eventually find out that he was a member of the British Army (472), but that this "paramilitary" experience also includes membership of a prison gang, the Twenty-Sevens (462). As a child he murdered his abusive father (470), but that is not why he went to prison. He went to prison after seemingly channelling his father's rage and killing his cheating girlfriend and her lover (476).

As with the discoveries around his parents' suppressed truths, Nico is shocked by these discoveries. At the end of the novel, however, he does not try to differentiate himself from his parental figures and distance himself from their crimes, as the reader might expect. He rather acknowledges that he is both his mother's and father's son (530) and Domingo's creation (515). According to Morton (Dark Ecology loc. 1990) this is the correct response to realizations acquired in the realm of guilt: one should not try to escape the guilt by, for instance, projecting it onto others, but should rather continue subscending down the ecognostic realms. Nico's discovery of his father's and Domingo's "guilt" can be read as parallels to the discovery of ecological guilt described by Morton. Nico's discovery of his mother's guilt, however, is not parallel to but rather an example of ecological illumination: Nico realises that agrilogistic attempts to solve ecological disasters born of the realm of anxiety lead to further disasters, and that he is implicated in these disastrous "crimes".

Domingo is a Darwinist and believes in "the survival of the most ruthless" (Meyer 123). He quotes the Afrikaans poet Nathan Trantraal to claim, "People 
Dark ecology and the representation of canids in Deon Meyer's Fever

are fragile creatures in a hostile environment" (152). Because of this, each person should be on the defence: "The other guy wants to kill me. If I hesitate, I die" (154). This conception of humanity is related to the idea that humans (and the individual human) are not separate from or elevated above the rest of the world. Dogs are central to Domingo's worldview:

Back in the day, before The Fever, every month or so you would read about a dog attacking a child or somebody. Major outrage, lawsuits, always aimed at the owner of the dog. But what people conveniently forget, dogs were once wolves. Before we tamed them. [...] And then we domesticated them, and gave them a veneer, a thin layer of civilization. One degree away from wild. [...] They kill each other, they kill everything they came across, they attack their former masters, they become wolf again. [...] And nobody understands. Because they don't want to, they can't afford to understand. Just like nobody can afford to understand when men do evil deeds. 'Cause we all believe man is the crown of creation, we're the animals who think and cry and laugh, noble creatures, how is it that we can murder? (175)

Willem sees dogs as a part of nature that humans need to overcome and Gaia One (and Nico's mother) implicitly sees humans as able to manipulate nature (with no need to take dogs into account). Domingo, on the other hand, views humans as like dogs in that they are seemingly separate from the rest of nature but are in fact entangled with it. He does not find it hard to believe that people murder. $\mathrm{He}$ does not believe that humans are different from the other animals. Like the dogs, humans were domesticated, but the fever removed our "thin veneer of civilization" (175). Domingo does not like his philosophy; he does not find solace in it. He sees it as "harsh" (175), but he does not try to escape from it. He is in what Morton calls the realms of melancholy and horror.

In using the term "melancholy", Morton is once again deliberately using a Freudian term to denote not only sadness, but also "the indigestible physical and psychic memory trace of other beings within oneself" (Dark Ecology loc. 2020). Domingo realises that he cannot escape the influence of other beings within himself-including his animal nature, his genetic make-up and the continued influence of his upbringing. It is not surprising that his philosophy is contrasted with that of Willem, Nkosi and most other citizens of Amanzi: "In a society where you are supposed to make yourself, givenness can get in the way. To have spent a lifetime molding oneself, only to find that one's environment was itself our mold, might be disconcerting" (loc. 2290). In the realms of melancholy and horror one discovers that autonomy is impossible, and "to be a thing at all is to have been hurt. To coexist is to have been wounded" (loc. 2300). In these realms, the individual can finally begin to dissolve the hard separation of subjects and objects to realise their own object status. Morton (loc. 2393) argues that it is important not to be stuck in these realms of intellectual knowing. It is important to move further down, into more productive realms. 


\section{Toward a logic of future co-existence}

As already explained, Morton argues that we should subscend through the realms of guilt, shame, disgust, melancholy and horror before we can reach a realm where we can find solutions through creative play. It is necessary to first move through all of these "dark" realms so that we can realise the seriousness of this play-so that it is not an attempt at transcendence or escape. It is also important that we do not try to devise solutions to ecological problems in the earlier realms, because solutions driven by anxiety, guilt, shame, disgust, melancholy or horror will inevitably be violent and agrilogistical (loc. 2393).

Ecognosis can only be reached if humans move past several further realms. The first is the realm of the ethereal, in which we give in to our fascination with kitsch. Here there is no excess, since everything that would usually be classified as waste becomes objects of fascination. Gothic pop music and art are created in this realm since the artist uses the abject, weird and excessive in their creations (loc. 2468).

Following the realm of the ethereal is the Spectral Plain, in which the distinction between subject and object are completely annihilated. To reach the Plain, humans must realise that any attempt to transcend the depressions of the already mentioned realms, is futile. Rather we should subscend into more and more real objects: "By real I mean not reified, not depending on a subject, not undermined or overmined: not reduced to atoms, fluxes, or processes or reduced upward to correlates of some Decider" (loc. 2509).

The Spectral Plain is followed by a realm of beauty in which humans allow objects that we find beautiful to act upon us. The beauty is difficult to pin down: it seems as if it originates in the object, but it emerges from the interaction between human and object. I, as a human, can only experience beauty if I surrender myself to it (loc. 2534). If this happens, I can also enter the realm of pleasure. This pleasure is erotic, a pleasure arising from the relationships between objects and from the recognition of the self as an object in relationships with other objects (loc. 2625).

The realm of the ethereal, the Spectral Plain and the realms of beauty and pleasure are not represented in the worldviews of any of Fever's protagonists. An indication of what a worldview born of these realms might look like, is however represented by the philosophies of two minor characters, Meklein and Vytjie. They are an elderly couple of Bushman and Griqua descent who Sofia Bergman lived with immediately following the fever (Meyer 198). After their death (due to old age) Sofia settles in Amanzi, but the reader is given a glimpse of her three years with them (204). Because of Meklein and Vytjie's knowledge of edible plants and traditional ways of hunting, they could be completely self-sufficient (204-5). From Meklein Sofia learned how to hunt with a bow and arrow: "He taught me to stalk and track, to survive in the veld. And at night beside the fire he described 
Dark ecology and the representation of canids in Deon Meyer's Fever

how his people would run after a wounded buck for hours and hours, how that was real hunting, the animals always stood a chance" (205).

Morton claims that "indigenous-that is, preagricultural" societies are better attuned to the ways in which humans can and should coexist with the nonhuman (Morton Dark Ecology loc. 2213). He specifically refers to the !Kung bushmen as having "a tolerance for ambiguity that would make the average deconstructor seem uptight by comparison" (loc. 1955). This is true of Meklein and his ancestors, who do not see humans as transcending their environment and the nonhumans. Humans are seen as part of the ecosystem, as are canids. This is why Meklein sees the fever as the result of the way humans have hurt the earth:

"Vytjie, when last did you see a gompou? He was talking about the kori bustard, that's what we called it, a gompou. [...] Remember the black eagles, when we were younger? There were so many. Remember the bakoortjies, how often we saw them in the old days? Those little bat-eared foxes are termite eaters, scorpion eaters, but the people thought they caught lambs. They never did. You don't see them any more. So many things you don't see any more. The old people hurt the earth, a lot. I wonder, is it not maybe the earth that sent the sickness?" (Meyer 218)

Canids-foxes rather than domesticated dogs-play a role in Meklein's worldview. His worldview is in direct contrast to Willem's focus on the protection of cattle and sheep from dogs. Sofia acknowledges that she romanticises her time with Meklein and Vytjie. Morton's claims about Bushman and "indigenous" societies can also be criticised for the way he, a Western outsider, romanticises a way of life he has no first-hand knowledge of. In Fever it is implied that while Meklein and Vytjie's lifestyles might be ideal in certain respects, it is also unsustainable: after their deaths Sofia is susceptible to manipulation by humans because she is used to trusting other people. She must also learn (agrilogistic) skills such as agriculture and shooting with a gun (307), in order to play her part in Amanzi. Still, her memories of Meklein and Vytjie serve as an indication that other forms of coexistence are possible. Meklein and Vytjie's hunter-gatherer existence does not entail the killing of canids to protect other animals viewed as humans' property.

Apart from the way in which Meklein and Vytjie's lives are represented as more ideal forms of coexistence, it should also be noted that Morton, in an article titled "An Object-Oriented Defence of Poetry" describes poetry in a way that brings to mind his descriptions of the realms of beauty and pleasure: "With remorseless gentleness, a poem forces us to acknowledge that we coexist with uncanny beings in a groundless yet vivid reality without a beyond" (222). When he or she reads poetry, the reader allows the poems to act upon him or her and take pleasure in this interaction. The novel-as-toy can therefore also be seen as such an object and the reading of a book (especially, in the case of Fever, such a gripping book) also entails surrendering to the pleasure to be had in a coexistence with our fellow 132 objects. 


\section{Conclusion}

The aim of this article is not to claim that Fever, a conventional post-apocalyptic thriller, finds fascination in the weird or the kitsch, or that it forces us to acknowledge our coexistence with uncanny beings in the same way that Morton claims for poetry. It, however, does illustrate the value of certain novels for dark ecology, in the way that it acts upon the reader in a manner that compels him or her to realise that imagining different forms of coexistence are possible. These different forms of coexistence are represented by the contrasts in different characters' worldviews. These worldviews often entail a specific view of the relationship between humans and canids. Gaia One's worldview is not explicitly related to canids, but the society seemingly did not consider the extent to which humanity's manipulation of nature will still be present (i.e. through the presence of domesticated dogs) even if the human population is reduced. The domestic dogs grown feral play a role in Willem's worldview, as he sees them as a part of nature that needs to be overcome in order for civilization to be re-established. Domingo and Meklein's view of canids come closer to a "letting be known" of those realizations that Morton associates with ecognosis. Domingo sees both humans and dogs as seemingly domesticated, but in fact entangled in nature. Meklein grieves for those canids (bakoortjies) killed by humans in their agricultural (and what Morton would call agrilogistic) pursuits.

\section{NOTES}

1. I am purposefully only using male pronouns to imply a relationship between the agrilogistic loop and the modernist patriarchal subject.

\section{WORKS CITED}

Bryant, Levi R. The Democracy of Objects. Open Humanities, 2011.

Freud, Sigmund. "The Uncanny." Commapress. <https://commapress.co.uk/resources/online-shortstories/the-uncanny-sigmund-freud/>. Accessed 6 Sep. 2018.

Hilfer, Anthony Channell. The Crime Novel: A Deviant Genre. U of Texas, 1990.

Krutnik, Frank. In a Lonely Street. Film Noir, Genre, Masculinity. Routledge, 2006.

Meyer, Deon. Fever. Hodder \& Stoughton, 2017.

Mies, Maria. "Self-determination: the end of utopia?" Ecofeminism. Eds. Maria Mies \& Vandana Shiva. Zed Books, 2014. pp. 218-30.

Morton, Timothy. “An Object-Oriented Defence of Poetry." New Literary History vol. 43, no. 2, 2012, pp. 205-24.

Dark Ecology: For a logic of future coexistence. Columbia U P 2016. E-book.

Ecology without Nature: Rethinking environmental aesthetics. Harvard U P, 2009.

Telotte, J. P. Voices in the Dark. The narrative patterns of Film Noir. U of Illinois, 1989.

Versfeld, Marthinus. Die neukery met die appelboom en ander essays. Protea, 2009. 